\title{
Sequential chemical extraction and mineralogical bonding of metals from Styrian soils
}

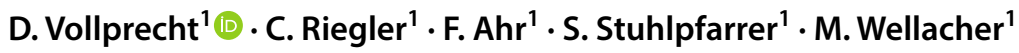

Received: 7 November 2019 / Revised: 11 February 2020 / Accepted: 19 February 2020 / Published online: 28 February 2020

(c) The Author(s) 2020

\begin{abstract}
Geogenic metal contaminations in soils are intensely discussed in waste management, as the recyclability of excavated soil is regulated by limit values for pseudo-total contents in Austria. However, the use of pseudo-total contents overestimates the release of some contaminants such as metals into the environment. Sequential extraction provides an empiric tool to better assess the mobility of metals and predicts their bonding type in individual fractions, but the relation between the obtained fractions and the exact mineralogical bonding is often unclear. Electron microprobe analyses provide detailed mineralogical insights, but do not yield direct information about the mobility of elements. A combination of both methods has been used a few times in soil sciences in general, but never to Styrian soils. Thus, six geogenic contaminated Styrian soils and one compost soil were investigated by a method combination of sequential chemical extraction and electron microprobe analyses. Sequential extraction suggested that $\mathrm{Cr}$ in five substrates and $\mathrm{As}$ and $\mathrm{Ni}$ in one substrate each are bound in stable crystalline minerals, whereas $\mathrm{Pb}$ in four samples and $\mathrm{Cu}$ in two samples are adsorbed to iron and manganese hydroxides. Elemental mappings obtained by electron microprobe analyses confirmed sequential chemical extraction results and specified that $\mathrm{Cu}$ and $\mathrm{Pb}$ are bound to manganese (hydr)oxides, $\mathrm{As}$ to $\mathrm{Fe}-\mathrm{Cu}-\mathrm{Sb}-\mathrm{S}$ compounds, $\mathrm{Cr}$ to spinels and $\mathrm{Ni}$ to olivine. In summary, the current study gives new information about the mobility and mineralogy of metals in six Styrian soils which is relevant for their possible recycling despite exceeded limit values for pseudo-total content.
\end{abstract}

Keywords Austria $\cdot$ Excavated material $\cdot$ Electron microprobe $\cdot$ Recycling $\cdot$ Tessier extraction

\section{Introduction}

Excavated soil is the largest waste stream in Austria making up $32 \mathrm{~m}$ tons and more than $50 \%$ of the overall waste in 2017 (Federal Ministry for Sustainability and Tourism 2019). Twenty-five metric tons or $78 \%$ are landfilled which means that valuable soil functions for humans and the environment (Drobnik et al. 2018) get lost instead of being maintained when used for recultivation purposes, e.g. through the production and application of compost soil, i.e. a synthetic soil substrate produced from compost and excavated soil (Wellacher et al. 2018). This is partly due to limit values

Editorial responsibility: M. Abbaspour.

D. Vollprecht

Daniel.vollprecht@unileoben.ac.at

1 Montanuniversität Leoben, Chair of Waste Processing Technology and Waste Management, Franz-Josef-Str. 18, 8700 Leoben, Austria regarding pseudo-total and leachable contents of metals and certain other parameters for the recycling of excavated soil (Federal Ministry for Sustainability and Tourism 2017). In this generalized expert opinion, in fact, pseudo-total contents derived by aqua regia digestion are given to define three classes intended for different recycling purposes, such as agricultural or non-agricultural use, A1, A2 and BA.

Thus, in Austria these limit values decide whether an excavated soil can be recycled or must be landfilled. Limit values for pseudo-total contents shift a huge amount of geogenically contaminated soils towards landfills where these soils lose their multitude of valuable functions, no matter these soils have been naturally grown and functioned over centuries.

Contrary, in other regions like Flanders, not the total contents, but only the emissions in air, surface water and groundwater are regulated (Cappuyns 2014). Consequently, the question arises if pseudo-total contents as limit values are the best way to assess the release of contaminants into the environment. This approach follows the precautionary 
principle that "where there are threats of serious or irreversible damage, lack of full scientific certainty shall not be used as a reason for postponing cost-effective measures to prevent environmental degradation" (The United Nations Conference on Environment and Development 1992). On the other hand, firstly, the release of contaminants from materials is limited by thermodynamic and kinetic restrictions like dissolution/precipitation or desorption/adsorption equilibria and reaction rates, respectively (Höllen et al. 2017). Secondly, positive recycling effects in terms of resource efficiency and maintenance of soil functions are gaining more attention and are suggested to outweigh the rather hypothetical threads without compromising environmental safety. This knowledge suggests that according to the European Commission which states that "the measures may have to be modified or abolished by a particular deadline, in the light of new scientific findings" (Commission of the European Communities 2000), pseudo-total contents of metals as limit values might be abolished if new findings reveal that only a minor fraction can be released into the environment.

Sequential chemical extraction (SCE) has been suggested and widely used as a tool to determine the mobility, availability, distribution and possible toxicity of chemical elements in soil already for 40 years (Tessier et al. 1979). It consists of a series of chemical extractions performed on the same sample using specific reagents to target individual fractions of chemical elements. In SCE, each reagent has a different chemical nature (e.g. a diluted acid, reducing or oxidizing agent) and the steps are performed roughly in order of increasing "vigor" (Rao et al. 2008). However, different SCE techniques vary in terms of significant aspects such as the choice and order of the extraction agent, the duration of the process and the solid/liquid ratio as well as the preparation and conservation of the samples (Filgueiras et al. 2002). Alternative concepts like parallel chemical extraction use different reagents for the initial soil sample (Quian et al. 1996). Another approach to assess metal mobility is electro-ultrafiltration (Jelecevic et al. 2019). Although such and several other alternatives like $\mathrm{pH}$-dependent leaching tests combined with hydrogeochemical modelling (Dijkstra et al. 2004) exist, which may provide a deeper insight in the mechanisms of contaminant release, SCE is still and often used in environmental sciences (Rodgers et al. 2019) though its future has been discussed controversially already more than a decade ago (Bacon and Davidson 2008). Tessier et al. (1979) linked the individual fractions obtained to mineralogical bonding (Table 1).

However, the minerals and organic compounds which were suggested to control the leaching of metals by either adsorption/desorption or precipitation/dissolution equilibria represent manifold groups of dozens to hundreds of phases whose individual members differ with respect to sorption capacity and solubility. Consequently, for a deeper understanding of metal mobility in soils a more profound knowledge about their mineralogical bonding is required. Eventually, this complex nature can be approached only by hypotheses, starting with simplified ones.

In contrast to Tessier et al. (1979) more recent research suggests that besides structurally incorporated metals, either by substitution or in stoichiometric phases, also recalcitrant organic compounds and resistant anthropogenic phases like elementary metals and vitreous phases can contribute to the so-called inert fraction (Young 2013) which corresponds to Tessier's residual fraction. However, Young (2013) defines also a "non-labile" metal fraction which is not bound reversibly, which can be the case for structurally incorporated metals, but also for surface complexes or nanoparticles. Consequently, the fact of structural incorporation alone does not allow the attribution to distinct mobilization behaviour.

Structural incorporation of metals in uncontaminated soils is limited to the substitution for main elements in mineral phases, as strong adsorption forces limit the availability of freely dissolved species, and organic acids might prevent the precipitation of e.g. chloropyromorphite $\left[\mathrm{Pb}_{5}\left(\mathrm{PO}_{4}\right)_{3} \mathrm{Cl}\right]$ (Lang and Kaupenjohann 2003; Young 2013). Although distinct metal phases have been found in some soils, e.g. $\mathrm{Zn}$ in franklinite $\left(\mathrm{ZnFe}_{2} \mathrm{O} 4\right)$ and sphalerite $(\mathrm{ZnS})$ in a smelterinfluenced soil (Roberts et al. 2002), these have been suggested not to control metal mobility (Degryse et al. 2009). However, it is still not completely clear if a solubility control of a metal might be valid for other cases, as amorphous $\mathrm{FeAsO}_{4}$ (Arcon et al. 2005), metallic $\mathrm{Pb}, \mathrm{PbCrO}_{4}$ (Jensen et al. 2006), $\mathrm{PbO}_{2}, \mathrm{~Pb}_{3} \mathrm{P}_{4} \mathrm{O}_{13}, \mathrm{Zn}(\mathrm{OH})_{2}, \mathrm{ZnO}$ and $\mathrm{Cd}(\mathrm{OH})_{2}$ (Hrsak et al. 2000) have been found as stoichiometric
Table 1 Fraction/mineralogical bonding and extractants according to Tessier et al. (1979)

\begin{tabular}{ll}
\hline Fraction/mineralogical bonding & Extractants \\
\hline Exchangeable & $1 \mathrm{M} \mathrm{MgCl}_{2}, \mathrm{pH} 7$ or $1 \mathrm{M} \mathrm{NaOAc}, \mathrm{pH} 8.2$, room temperature, $1 \mathrm{~h}$ \\
Bound to carbonates & $1 \mathrm{M} \mathrm{NaOAc}, \mathrm{pH} 5.0$ (adjusted by HOAc), room temperature, $5 \mathrm{~h}$ \\
Bound to Fe-Mn oxides & $0.3 \mathrm{M} \mathrm{Na}_{2} \mathrm{~S}_{2} \mathrm{O}_{4}+0.175 \mathrm{M} \mathrm{Na}-\mathrm{citrate}+0.025 \mathrm{M} \mathrm{H}$-citrate or \\
& $0.04 \mathrm{M} \mathrm{NH}_{2} \mathrm{OH} \cdot \mathrm{HCl}$ in $25 \%(\mathrm{v} / \mathrm{v}) \mathrm{HOAc}, 90-95^{\circ} \mathrm{C}, 6 \mathrm{~h}$ \\
Bound to organic matter & $0.02 \mathrm{M} \mathrm{HNO}_{3}+30 \% \mathrm{H}_{2} \mathrm{O}_{2}, \mathrm{pH} 2\left(\right.$ by $\mathrm{HNO}_{3}$ ), $85^{\circ} \mathrm{C}, 2 \mathrm{~h}$; addi- \\
& tion of $\mathrm{NH}_{4} \mathrm{OAc}$ after cooling to prevent adsorption \\
Residual = incorporated in minerals & $\mathrm{HF}-\mathrm{HClO}_{4}$ mixture \\
\hline
\end{tabular}


metal-containing minerals in contaminated soils, and solubility control has been demonstrated to be a possible leaching controlling mechanism in other anthropogenic materials like steel slags (Höllen et al. 2017).

Several attempts have been taken to link the heavy mobility obtained by SCE to the mineralogical bonding of heavy metals in soil samples. Moral et al. (2005) found that $\mathrm{Cd}$, Ni, $\mathrm{Cr}, \mathrm{Co}, \mathrm{Ag}, \mathrm{Pb}, \mathrm{Cu}, \mathrm{Mn}$ and $\mathrm{Zn}$ in Spanish soils were mostly present in the residual, reducible and carbonate-sorbed form, but could not locate them by scanning electron microscopy using energy-dispersive X-ray spectroscopy (SEM-EDX) which suggests general dispersion throughout the soil matrix. Beesley and Marmiroli (2011) used SEM/EDX to illustrate a relative concentration decrease in $\mathrm{As}, \mathrm{Cd}$ and $\mathrm{Zn}$ from soil during leaching tests, but could also not identify the exact mineralogical bonding of these metals. These studies indicate that methods with lower detection limits than SEM-EDX are required for this purpose.

Cerqueira et al. (2011) combined time of flight secondary ion mass spectrometry (TOF-SIMS) and high resolution transmission electron microscopy with energy-dispersive $\mathrm{X}$-ray spectroscopy (HR-TEM/EDX) to show that $\mathrm{Cu}^{2+}$ and $\mathrm{Pb}^{2+}$ in a luvisol soil were associated with haematite, gibbsite, vermiculite and chlorite. Cerqueira et al. (2012) used HR-TEM to prove the incorporation of $\mathrm{Cr}$ and $\mathrm{Cu}$ into haematite and of $\mathrm{Pb}$ and $\mathrm{Cu}$ in jarosite and schwertmannite. Arenas-Lago et al. (2014) found, investigating soils from a depleted mine in Lugo, Spain, that the majority of the Cd, $\mathrm{Pb}$ and $\mathrm{Zn}$ proportion is in the residual fraction of the soil using TOF-SIMS to confirm results of sequential chemical extraction. Field emission secondary electron microscopy (FE-SEM) images also showed the presence of residual $\mathrm{Zn}$ associated with $\mathrm{Fe}$ oxides and $\mathrm{Pb}^{2+}$ deposited on calcite and microcline.

As the detection limit of SEM-EDX is often too high and the costs for TOF-SIMS are too high, electron microprobe analyses (EMPA) represent an intermediate method to determine the mineralogical bonding of chemical elements in soils and to compare it to SCE. Borgigno et al. (2006) compared SCE and EMPA with respect to phosphorous and showed that $\mathrm{Ca}-$ and Fe-bound phosphate species represent the largest fractions. With respect to heavy metals, Basu and Schreiber (2013) found Fe hydroxides as the main As fraction according to SCE, but could show by EMPA that weathering of arsenopyrite to As-bearing hydroxides occurs via the formation of scorodite. Byrne et al. (2017) found that $\mathrm{Cr}$ was bound in the residual fraction of urban sediments according to SCE and specified by EMPA that it is bound to Fe oxides and alumino-silicate glass. Kierczak et al. (2008) successfully combined SCE and EMPA with respect to the mobility and speciation of $\mathrm{Cr}, \mathrm{Ni}$ and $\mathrm{Zn}$, but could not identify the mineralogical bonding of the mobile elements $\mathrm{Cu}$ and $\mathrm{Pb}$ due to low concentrations. Fleming et al. (2013) combined SCE with EMPA for Pb and As and found them to be present as in discrete particles along with $\mathrm{P}$ and $\mathrm{Fe}$. Finally, Nielsen et al. (2015) successfully combined SCE and EMPA to show the association of $\mathrm{Cu}$ with organic matter in a contaminated soil in Denmark.

For Austrian soils, both SCE (Hseu et al. 2017) or EMPA (Sedlazeck et al. 2017) were used separately to investigate the speciation of heavy metals, but only one study (Lombi et al. 2000) combined these methods and found by both methods that As was bound to Fe hydroxides in the investigated samples. No studies on the combination of SCE and EMPA with respect to the mobility of other elements were found for Austrian soils, and none of the investigated soils from Lombi et al. (2000) was from the province of Styria.

Consequently, the aim of the present study is to characterize the mobility of metals in geogenically contaminated soils from the Styria in which contaminations from non-ferrous metal mining and metallurgy are quite abundant (Krainer 1999) by SCE and to test the link between mineralogical bonding and SCE. The novelty of this study, i.e. the difference to other papers, is not the method combination itself, but its application to a specific set of samples in a specific context which has two dimensions.

Firstly, the number of possible mineralogical bonding forms of a metal is higher than the number of SCE fractions, especially with respect to the residual fraction. This means that a metal which is mainly bound to the same SCE fraction in two soils may be incorporated in different minerals though. Consequently, application of the suggested method combination for a large number of soils is required for a deeper understanding of the relation between mineralogy and mobility of metals in soils, and the additional case studies from Styria present here are an important novelty.

Secondly, the waste legislation varies between different countries. Austria is a country which regulates pseudo-total contents of metals for the recycling of excavated waste. This inhibits the recycling of excavated soil, especially in regions with geogenic enrichments and a mining history like Styria. Austrian waste legislation does neither consider SCE nor EMPA as tools to assess the recyclability of excavated soils. Therefore, the application of the method combination in this specific waste management context represents a significant novelty. Consequently, one objective of this study is to deliver arguments to the authorities to replace pseudototal-content limit values for excavated soil recycling by a mobility-based approach.

\section{Materials and methods}

\section{Materials}

Seven Styrian soils (L1, L2, L3, L5, L7, L11 and L12) and one artificial compost soil (L22) have been sampled. All soil 
samples except L3 are geogenically contaminated with metals (Fig. 2). L3 served as reference soil without any metal contents exceeding limit values. Soil samples were collected according to ÖNORM L1056 (Austrian Standards International 2004) by taking at least 25 individual samples at each sampling site with a "Pürckhauer" and merging them to a mixed sample from a depth of $10-30 \mathrm{~cm}$. The compost soil sample was prepared by mixing serpentine sand $<4 \mathrm{~mm}$ with compost and excavated soil in the weight ratio 69:11:20 and taken according to ÖNORM S2127 (Austrian Standards International 2011). If the samples were not prepared right away after sampling, they were stored at $0-4{ }^{\circ} \mathrm{C}$.

\section{Methods}

\section{Physico-chemical characterization}

Samples were pre-treated based on EN 16179, i.e. dried at $4{ }^{\circ} \mathrm{C}$ until constant weight, divided by the quartering method, manually disaggregated and sieved $(2 \mathrm{~mm})$. Only the fraction $<2 \mathrm{~mm}$ was used for all analyses and experiments.

For chemical analyses, samples were grinded (ball mill, Retsch S 1000) and dried at $105 \pm 3^{\circ} \mathrm{C}$ [drying oven, according to ÖNORM EN 14346 (Austrian Standards International 2007)] prior to microwave digestion with a mixture of HF, $\mathrm{HNO}_{3}$ and $\mathrm{HCl}$ according to ÖNORM EN 13656 (method A) (Austrian Standards International 2002a). At the same time, an aqua regia digestion according to ÖNORM EN 13657 (method B) (Austrian Standards International 2002b) was conducted. The digested samples were analysed by inductively coupled plasma mass spectroscopy (ICP-MS, Agilent $7500 \mathrm{ce}$ ) according to ÖNORM EN ISO 17294-2 (Austrian Standards International 2017) for total contents of $\mathrm{As}, \mathrm{Pb}$, $\mathrm{Cd}, \mathrm{Cr}, \mathrm{Cu}, \mathrm{Ni}$ and $\mathrm{Hg}$.

Soil-specific physico-chemical analyses were conducted at the Agricultural Testing Facility of Styria (LwVzSt) in Graz. Samples were prepared according to ÖNORM L 1053 (Austrian Standards International 2012b). pH was determined according to ÖNORM EN 15933 (Austrian Standards International 2012a), the specific electric conductivity according to ÖNORM L 1099 (Austrian Standards International 2015), the plant-available $\mathrm{P}$ and $\mathrm{K}$ according to ÖNORM L 1087 (Austrian Standards International 2019a), the total $\mathrm{N}$ using the Kjeldahl method according to ÖNORM EN 16169 (Austrian Standards International 2012c), the carbonate content using the Scheibler method according to ÖNORM L 1084 (Austrian Standards International 2016), the total organic carbon (TOC) according to ÖNORM L 1080 (Austrian Standards International 2013) and the particle size distribution according to ÖNORM L 1061-2 (Austrian Standards International 2019b).

\section{Sequential chemical extraction}

SCE experiments were conducted for each of the investigated samples in duplicate or triplicate according to Tessier et al. (1979) in four steps:

1. Four grams of each sample was placed in a centrifuge beaker, $32 \mathrm{~mL} 1 \mathrm{M} \mathrm{MgCl}_{2}$ extraction solution was added and samples were shaken for $1 \mathrm{~h}$ at room temperature. Solids were separated from remaining solutions (fraction 1) by centrifugation at $5500 \mathrm{rpm}$ for $15 \mathrm{~min}$. The supernatant was pipetted, and the solid residue was washed with at least $10 \mathrm{~mL}$ of deionized water and centrifuged again for $15 \mathrm{~min}$. This time the supernatant liquid was discarded, the solid was dried, weighed and used for the next step.

2. The solid fraction remaining after step 1 was mixed with $32 \mathrm{~mL} 1 \mathrm{M}$ sodium acetate solution and shaken for $5 \mathrm{~h}$ at room temperature. Again, centrifugation was used to separate solids from the solution and washing, weighing and drying were carried out.

3. The solid fraction remaining after step 2 was mixed with $80 \mathrm{~mL}$ of a $1 \mathrm{M} \mathrm{NH}_{2} \mathrm{OH} \cdot \mathrm{HCl}$ solution (adjusted to $\mathrm{pH} 5$ by $\mathrm{AcH}$ ) and heated at $96 \pm 3{ }^{\circ} \mathrm{C}$ for $6 \mathrm{~h}$. A watch glass was used on top of the water bath to allow the evolving gases to escape. After cooling, solids were separated from the solution by centrifugation, etc.

4. The solid fraction remaining after step 3 was mixed with $12 \mathrm{~mL}$ of a $0.02 \mathrm{M} \mathrm{HNO}_{3}$ solution and $20 \mathrm{~mL}$ of a $30 \% \mathrm{H}_{2} \mathrm{O}_{2}$ solution and heated at $85 \pm 2{ }^{\circ} \mathrm{C}$ for $3 \mathrm{~h}$. Another $12 \mathrm{~mL}$ of a $30 \% \mathrm{H}_{2} \mathrm{O}_{2}$ solution were added and the extraction continued for $3 \mathrm{~h}$. After cooling, $20 \mathrm{~mL}$ of a $3.2 \mathrm{M} \mathrm{NH}_{4} \mathrm{OAc}$ in $20 \%(\mathrm{v} / \mathrm{v}) \mathrm{HNO}_{3}$ were added and the mixture was shaken for $30 \mathrm{~min}$. Again the sample was centrifuged to separate solids from the liquid.

5. The residue of step 4 was weighed and digested using hydrofluoric acid and analysed (method A).

In each SCE run a reference sample (L3) was simultaneously treated to guarantee the reproducibility of method and results. All obtained aqueous solutions were analysed by inductively coupled plasma mass spectroscopy (ICP-MS, Agilent 7500ce) according to ÖNORM EN ISO 17294-2 for $\mathrm{As}, \mathrm{Pb}, \mathrm{Cd}, \mathrm{Cr}, \mathrm{Cu}, \mathrm{Ni}$ and $\mathrm{Hg}$. Concentrations of individual elements in the solutions are converted to the weight of the dry matter of the initial sample.

\section{Electron microprobe analyses}

One polished section was prepared from each sample (apart from L3, as all considered metal contents were below $50 \mathrm{mg} / \mathrm{kg}$ ) and analysed by electron microprobe analyses (EMPA, Superprobe Jeol JXA 8200, U =15 kV, A = $10 \mathrm{nA}$ ). 

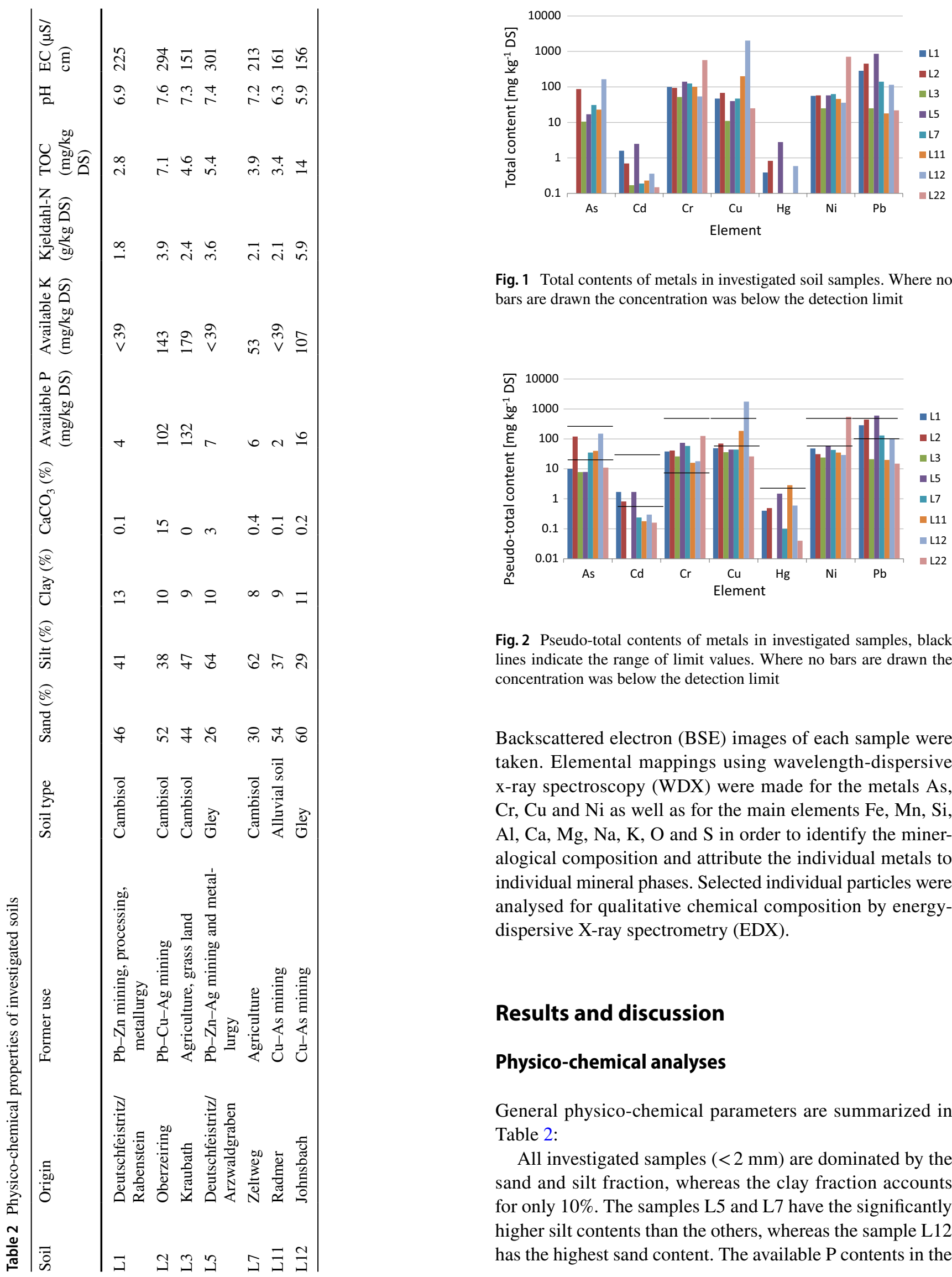

Fig. 1 Total contents of metals in investigated soil samples. Where no bars are drawn the concentration was below the detection limit

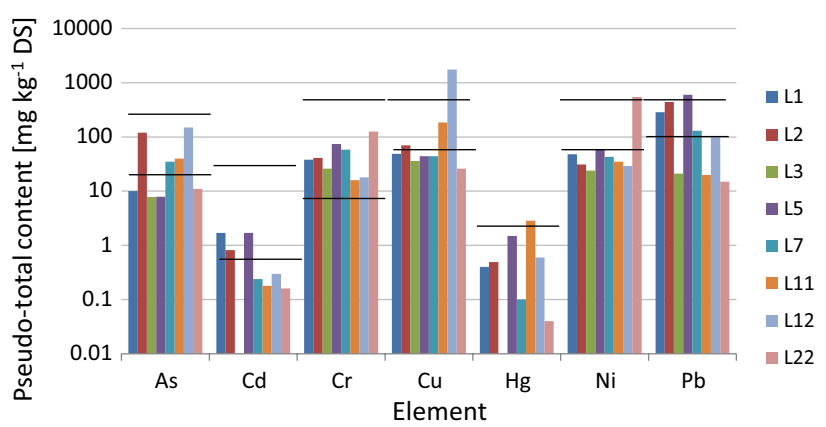

Fig. 2 Pseudo-total contents of metals in investigated samples, black lines indicate the range of limit values. Where no bars are drawn the concentration was below the detection limit

Backscattered electron (BSE) images of each sample were taken. Elemental mappings using wavelength-dispersive $\mathrm{x}$-ray spectroscopy (WDX) were made for the metals As, $\mathrm{Cr}, \mathrm{Cu}$ and $\mathrm{Ni}$ as well as for the main elements $\mathrm{Fe}, \mathrm{Mn}, \mathrm{Si}$, $\mathrm{Al}, \mathrm{Ca}, \mathrm{Mg}, \mathrm{Na}, \mathrm{K}, \mathrm{O}$ and $\mathrm{S}$ in order to identify the mineralogical composition and attribute the individual metals to individual mineral phases. Selected individual particles were analysed for qualitative chemical composition by energydispersive X-ray spectrometry (EDX).

\section{Results and discussion}

\section{Physico-chemical analyses}

General physico-chemical parameters are summarized in Table 2:

All investigated samples $(<2 \mathrm{~mm})$ are dominated by the sand and silt fraction, whereas the clay fraction accounts for only $10 \%$. The samples L5 and L7 have the significantly higher silt contents than the others, whereas the sample L12 has the highest sand content. The available $\mathrm{P}$ contents in the 


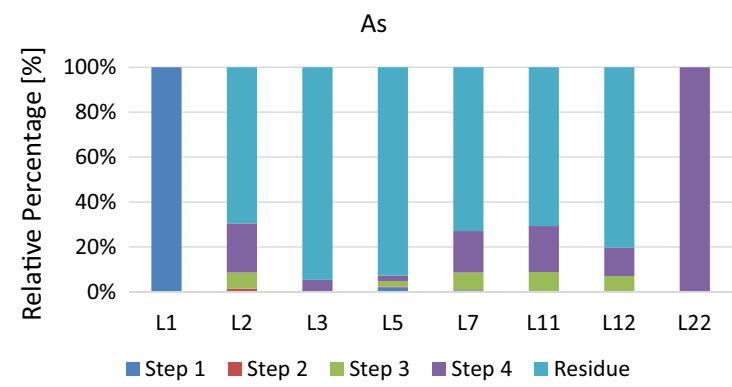

$\mathrm{Cu}$

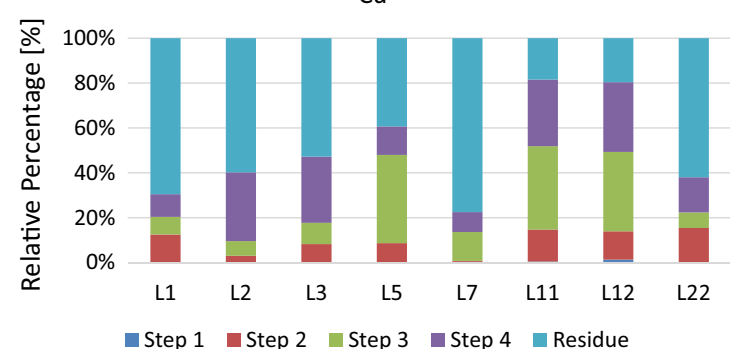

$\mathrm{Pb}$

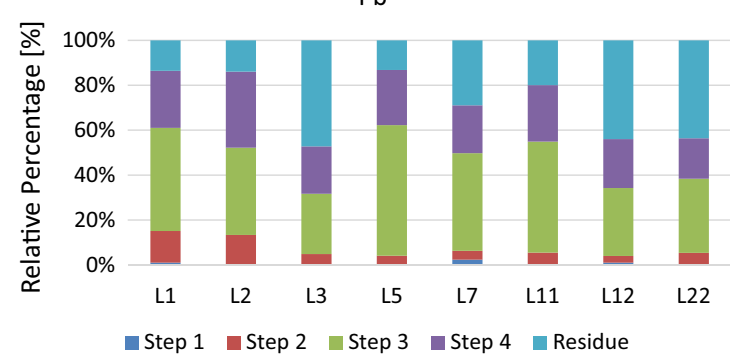

$\mathrm{Cr}$

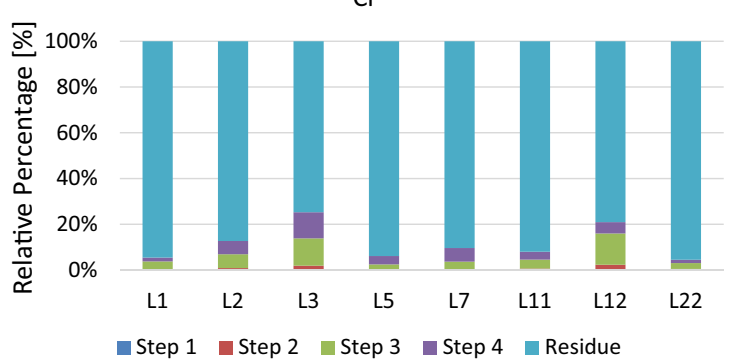

$\mathrm{Ni}$

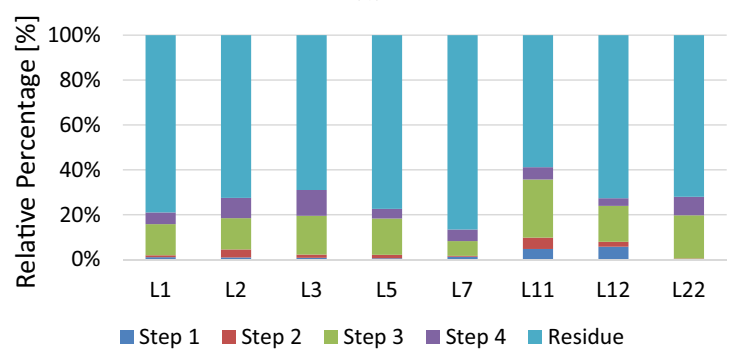

$\mathrm{Cd}$

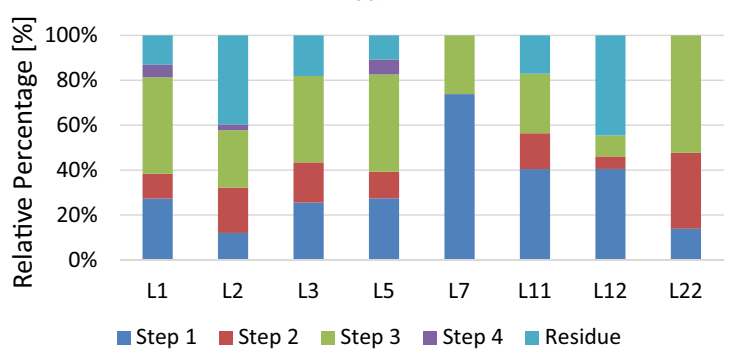

Fig. 3 Sequential chemical extraction of individual metals from soil (L1 - L12) and compost soil (L22) samples. Relative percentages of total concentrations are presented

samples L2 and L3 are one order of magnitude above those of the other samples and also the $\mathrm{K}$ contents are about three times higher. The soil L12 has a much higher TOC content than the other samples. The $\mathrm{pH}$ of the samples is in the nearneutral range, and the electric conductivity varies between 150 and $300 \mu \mathrm{S} / \mathrm{cm}$.

Chemical analyses of investigated samples (Fig. 1) indicate that $\mathrm{Cr}, \mathrm{Cu}, \mathrm{Ni}, \mathrm{As}$ and $\mathrm{Pb}$ are present in total contents (method A) between 10 and $1000 \mathrm{mg} / \mathrm{kg}$, whereas $\mathrm{Cd}$ and $\mathrm{Hg}$ occur mostly in concentrations below $1 \mathrm{mg} / \mathrm{kg}$. Variations between individual samples are mostly in the range of one order of magnitude. A specific observation for $\mathrm{Cr}$ and $\mathrm{Ni}$ is that here only sample L22 shows significantly higher concentrations than other samples which are in the same range. Sample L3 is characterized by the lowest contents of all considered metals.

Pseudo-total contents (method B) were determined for comparison with limit values from legislation (Fig. 2).

Four samples, i.e. L5 (Pb), L11 ( Hg), L12 (Cu) and L22 (Ni), exceed the highest limit value for the respective element and might not be recycled at all according to the current Austrian legislation. L1, L2 and L7 keep the highest limit value for all elements, but exceed the lowest limit value for at least one parameter, thus suffer restrictions in its recyclability, whereas L3 fulfils even the lowest limit values for all elements. This is in agreement with the fact that L3 was taken as a reference sample where no contaminations were suspected.

\section{Sequential chemical extraction}

SCE analyses generally indicate that the same elements in different samples follow the same trend (Fig. 3). Arsenic, $\mathrm{Cr}$ and $\mathrm{Ni}$ follow a progressive trend, i.e. the larger portion of these metals is bound to less mobile fractions. In average, $87 \pm 8 \%$ of $\mathrm{Cr}, 80 \pm 11 \%$ of As and $74 \pm 9 \%$ of $\mathrm{Ni}$ are bound to the residual fraction. Consequently, $\mathrm{Cr}$ was found to be the least mobile metal.

In contrast, $\mathrm{Cd}$ and $\mathrm{Pb}$ show a degressive behaviour, i.e. that the larger portion of those metals is more mobile. However, compared the enrichment in the largest fraction 


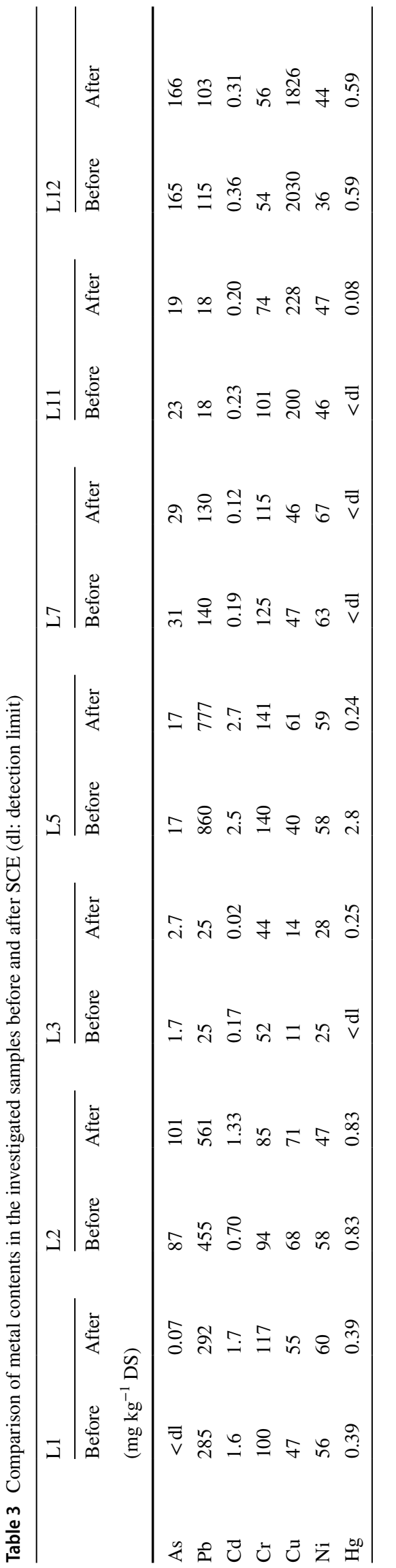

is less pronounced. $42 \pm 12 \%$ of $\mathrm{Pb}$ are extracted within the third fraction and $26 \pm 15 \%$ to the residue. $\mathrm{Cd}$ is the most mobile element with $35 \pm 20 \%$ bound to the first fraction and $30 \pm 12 \%$ to the third fraction as the fractions with the biggest load.

Copper shows an intermediate behaviour with rather even distribution among the fractions (e.g. each $30 \%$ in the third and fifth fraction), although $48 \pm 23 \%$ are extracted within the residual fraction in average.

Mercury could not be detected in most of the fractions so that its behaviour in SCE cannot be described adequately. This was probably due to the vaporization of almost all $\mathrm{Hg}$ during the high temperature steps 3 and 4 .

SCE analyses furthermore show that different elements in the same sample behave differently.

Comparing the trend for individual metals in soils with high and low contents of these metal, e.g. in the case of As, shows no difference in the behaviour between the sample groups. Sample L2, which has the by far highest $\mathrm{CaCO}_{3}$ content (Table 2), does not show a higher fraction of the heavy metals bound to the carbonate fraction than other samples do. This demonstrates that the simple presence of carbonates does not mean that heavy metals are bound to carbonates. In case of elements showing a progressive trend, it is suggested that the solubility of the heavy-metal-bearing minerals in the residual fraction is so low that the resulting dissolved concentrations are not sufficient for the precipitation of heavy metal carbonates. In case of elements showing a degressive behaviour, the high share of exchangeable fractions indicates the presence of highly soluble heavy metal species. The presence of carbonates does not seem to represent a secondary sink for these elements during the first extraction step of TCE. This suggests that the incorporation of heavy metals into the pre-existing carbonates is either too slow (e.g. due to slow diffusion) or thermodynamically inhibited (e.g. due to too low $\mathrm{pH}$ ).

The reproducibility of SCE results was confirmed by measuring the sample L3 as a reference sample in each SCE series. RSD of the cumulatively extracted fractions including the final HF digestion of the residue between all L3 samples is in the range of 10 to $20 \%$ for most metals.

The validity of SCE results was confirmed by comparing the total contents in each sample with the cumulatively extracted amounts including final HF digestion which deviated only 10 to $20 \%$ from each other (Table 3 ). In general, recovery rates are in the range of $100 \%$, i.e. the mass balance is correct. Significant deviations occur for metals which are present in concentrations below $10 \mathrm{mg} / \mathrm{kg}$ for some cases, e.g. for As in L3, Cd in L2 and L3, whereas in other cases the contents before and after the experiments match very well despite low contents, e.g. for Cd in L1, L5, L11 and L12. 


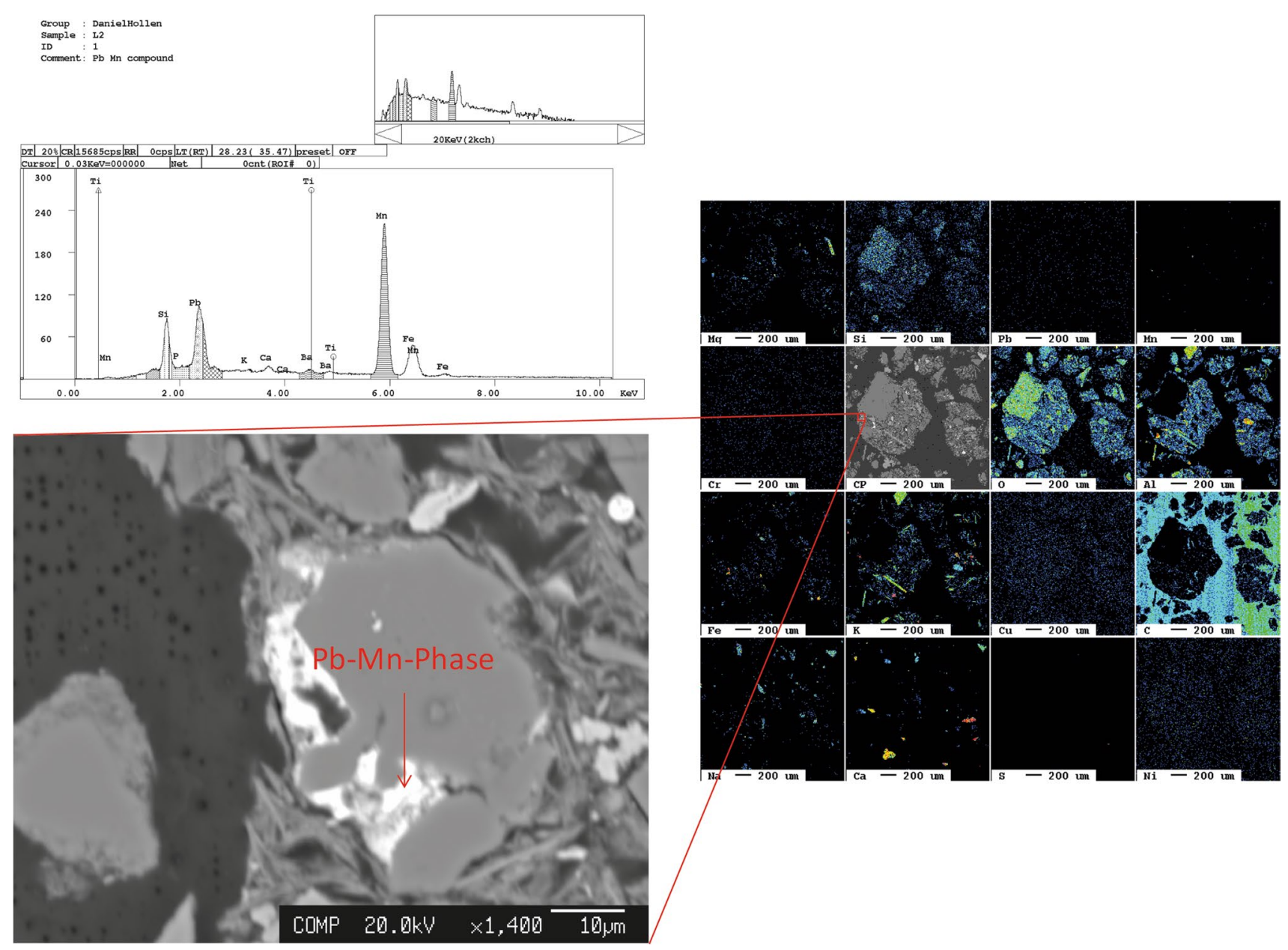

Fig. 4 EDX spectrum (top left) indicating the presence of $\mathrm{Pb}$ and Mn, BSE image (bottom left) of the corresponding particle, elemental mapping (right) of a wider area of sample L2

SCE results are in rough agreement with a study on soil reference materials ( $\mathrm{Li}$ et al. 1995). Cr was predominantly bound to the residual fraction in their used reference material SO-1-4 (89\%) and in the investigated samples $(87 \pm 8 \%)$. Ni is more mobile than $\mathrm{Cr}$ as the share in the residual fraction was lower both in reference material USGS MAG-1 (65\%) and the investigated samples $(74 \pm 9 \%)$. $\mathrm{Cu}$ is less mobile in USGS MAG- 1 as 73 to $91 \%$ were bound to the residual fraction, compared to only $48 \pm 23 \%$ in our samples. The higher $\mathrm{Cu}$ mobility in the investigated samples might be explained by the presence of sulphide minerals like tetrahedrite whose weathering releases $\mathrm{Cu}$ in the advanced state (Majzlan et al. 2018). Contrary, $\mathrm{Pb}$ is more mobile in the investigated samples where it is predominantly $(42 \pm 11 \%)$ bound to the third fraction, whereas it is dominant (53 to 62\%) in the residual fraction in USGS MAG 1. This suggests that in USGS MAG-1 primary $\mathrm{Pb}$ minerals might control the mobility, whereas the investigated soils might have been infiltrated by dissolved $\mathrm{Pb}$. SCE data for $\mathrm{Hg}$ were not presented as careful assessment of the analyses and experimental procedures suggested that $\mathrm{Hg}$ might have vaporized during heating in steps 3 and 4 of the SCE.

The order of mobility of elements in this study $(\mathrm{Cd}>\mathrm{Pb}>\mathrm{Cu}>\mathrm{Ni}>\mathrm{As}>\mathrm{Cr})$ is in general agreement with literature data. The rapid mobilization of $\mathrm{Cd}$ in soils and the slower oxidation and trapping of $\mathrm{Pb}$ in clay minerals have been described in detail (Kabata-Pendias and Pendias 2001). The orders $\mathrm{Cd}>\mathrm{Pb}>\mathrm{Ni}$ and $\mathrm{Cu}>\mathrm{Cr}$ were also found in floodplain soils along the Elbe river in Germany (Rinklebe and Shaheen 2014; Shaheen and Rinklebe 2014). In floodplain soils along the Pinios river (Greece) and the Nile river (Egypt), a smaller amount of $\mathrm{Cd}, \mathrm{Cu}, \mathrm{Ni}$ and $\mathrm{Pb}$ was found in the mobile fraction (Shaheen et al. 2015). The relatively low mobility of $\mathrm{Ni}$ with a larger portion in the residual fraction and smaller fractions of acid-soluble $\mathrm{Ni}$ are in agreement with data for serpentine soils (Hseu et al. 2017). 


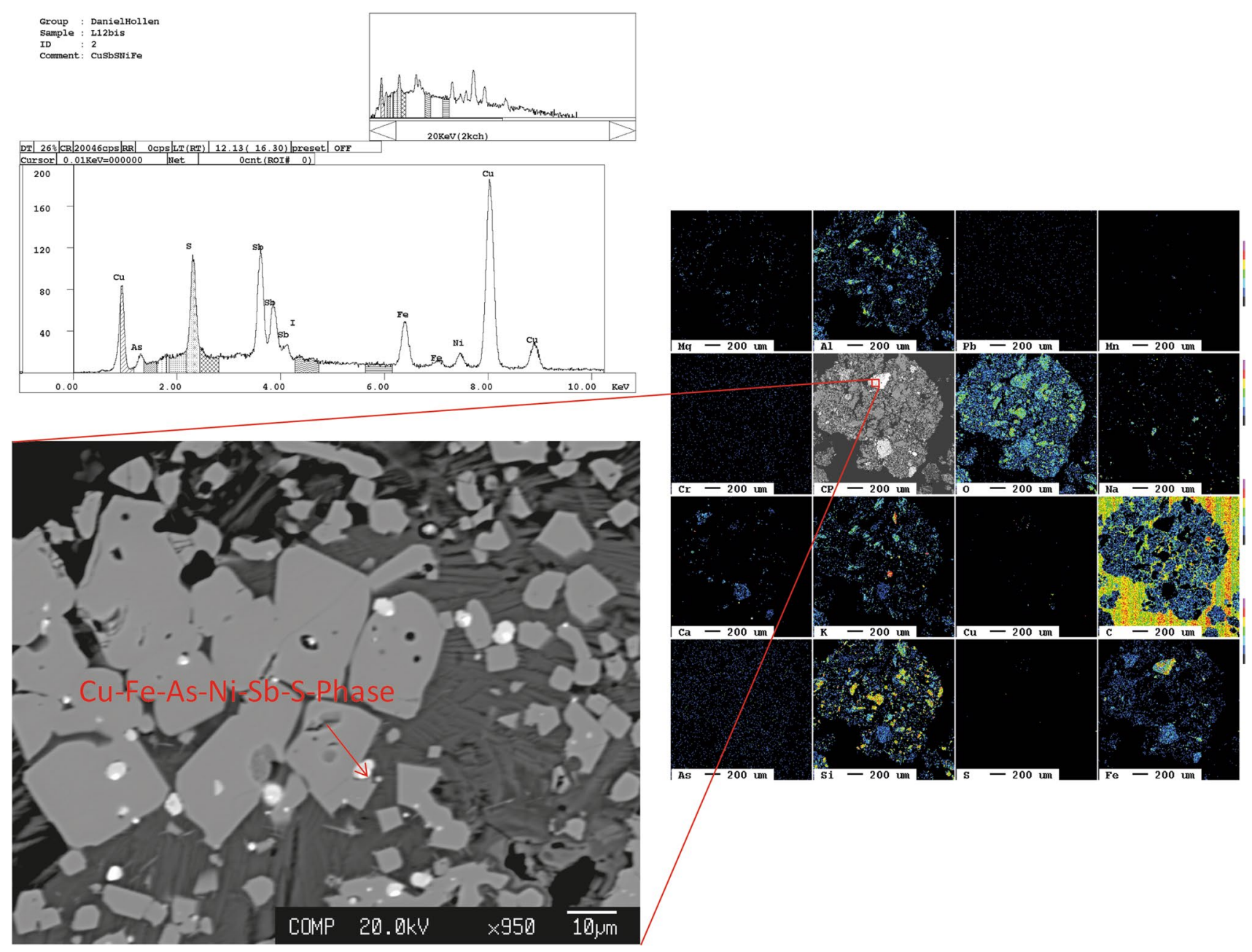

Fig. 5 EDX spectrum (top left) indicating the presence of $\mathrm{Cu}, \mathrm{Fe}, \mathrm{Ni}, \mathrm{Sb}$, As and S, BSE image (bottom left) of the corresponding particle, elemental mapping (right) of a wider area of sample L12

\section{Electron microprobe analyses}

EMPA results indicate the mineralogical bonding of at least one metal in all investigated samples apart from L11. However, only the mineralogical bonding of one element could be determined for $\mathrm{L} 1(\mathrm{Cr}), \mathrm{L} 2(\mathrm{~Pb})$ and $\mathrm{L} 5(\mathrm{~Pb})$ and of two elements for $\mathrm{L} 7(\mathrm{Cr}, \mathrm{Pb}), \mathrm{L} 12(\mathrm{As}, \mathrm{Cu})$ and $\mathrm{L} 22(\mathrm{Cr}, \mathrm{Ni})$.

EMPA results show that $\mathrm{Pb}$ and $\mathrm{Mn}$ occur together in sample L2 (Fig. 4). It is proposed that the Si peak which is also visible in the EDX spectrum is due to the adjacent quartz grain at the top left. The other peaks are only from $\mathrm{Pb}$ and $\mathrm{Mn}$. As neither $\mathrm{O}$ nor $\mathrm{H}$ can be identified by EDX, but oxygen can be seen at the corresponding area in WDX, the presence of a $\mathrm{Pb}-\mathrm{Mn}$ (hydr)oxide can be deduced. However, despite partly high $\mathrm{Pb}$ contents in sample $\mathrm{L} 1(285 \mathrm{mg} / \mathrm{kg})$, neither elemental mappings nor EDX analyses of individual particles could reveal the mineralogical bonding of $\mathrm{Pb}$ in those samples.
Copper is present in a complex $\mathrm{Cu}-\mathrm{Fe}-\mathrm{Ni}-\mathrm{Sb}-\mathrm{As}-\mathrm{S}$ compound in sample L12 (Fig. 5) as these elements were identified in the same grain according to EDX measurements. However, as no distinct phase with this composition could be found in the literature, it is suggested that this grain is composed of different phases from the large group of sulfosalts. Unfortunately, for all other investigated samples, the mineralogical bonding of $\mathrm{Cu}$ could not be revealed although its total content in sample L11 was $200 \mathrm{mg} / \mathrm{kg}$. Arsenic was also identified in the same compound in sample L12.

Chromium is incorporated in spinels $\left[(\mathrm{Fe}, \mathrm{Mg})(\mathrm{Al}, \mathrm{Cr})_{2} \mathrm{O}_{4}\right]$ in samples L1, L7 and L22 (Fig. 6). Again, although some other samples showed higher total $\mathrm{Cr}$ contents than those 


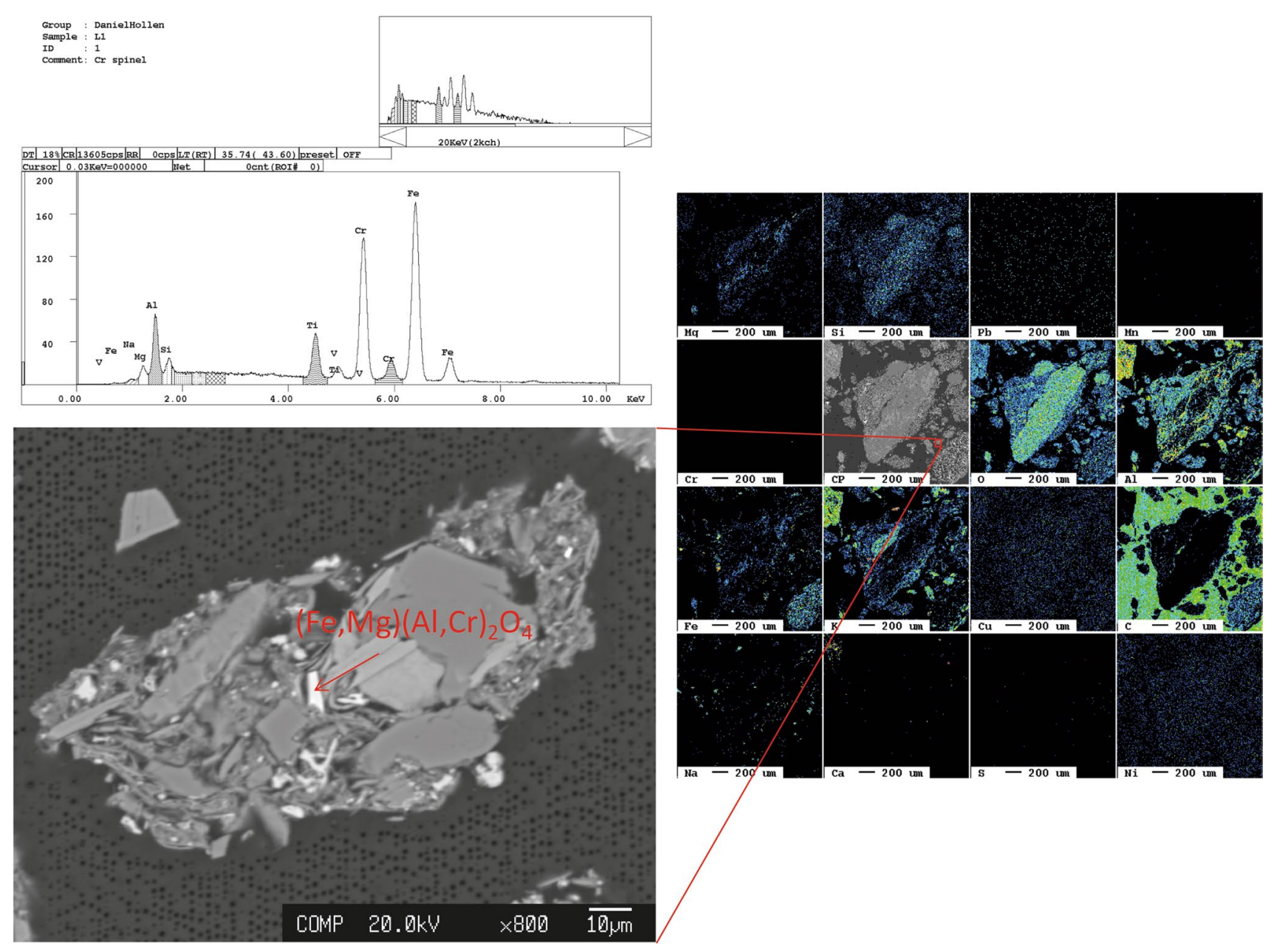

Fig. 6 EDX spectrum (top left) indicating the presence of Fe, Cr and Al, BSE image (bottom left) of the corresponding particle, elemental mapping (right) of a wider area of sample L1

(e.g. L5: $140 \mathrm{mg} / \mathrm{kg}$ ), the mineralogical bonding of $\mathrm{Cr}$ could not be determined in them. For Ni, EMPA results reveal that it is present as olivine, which has the stoichiometric formula $\left[(\mathrm{Fe}, \mathrm{Mg})_{2} \mathrm{SiO}_{4}\right]$, but can incorporate some $\mathrm{Ni}$ instead of $\mathrm{Fe}$ or $\mathrm{Mg}$ (Santos et al. 2015). As all other samples have total Ni contents of maximum $63 \mathrm{mg} / \mathrm{kg}$, it is consistent that EMPA could not reveal its mineralogical bonding therein.

EMPA results generally confirm the hypothesis of SCE regarding the mineralogical bonding of investigated samples and give more precise information about the exact phase the metals are bound to (Table 4). On the other hand, SCE results suggest also the mineralogical bonding of minor fractions of metals, whereas EMPA only show one host phase for each metal.

$\mathrm{Pb}$, which is mostly present in fraction 3, i.e. suggested to be bound to $\mathrm{Fe}$ and Mn (hydr)oxides according to SCE, in samples L2, L5 and L7, is confirmed to be present as $\mathrm{Pb}-\mathrm{Mn}$ phase. Regarding the identification of $\mathrm{Pb}-\mathrm{Mn}$ hydroxides in sample $\mathrm{L} 2$, the presence of the $\mathrm{Pb}-\mathrm{Mn}$ silicate yangite, $\mathrm{PbMnSi}_{3} \mathrm{O}_{8} \cdot \mathrm{H}_{2} \mathrm{O}$ (Downs et al. 2016), cannot be excluded. Due to the drying process of the sample during sample preparation, it cannot be distinguished if $\mathrm{Pb}$ is adsorbed to a $\mathrm{Mn}$ (hydr)oxide or incorporated in its structure, as during the drying process precipitation of adsorbed species would have occurred. Furthermore, it is not clear if the $\mathrm{Pb}$-bearing phase is an oxide or a hydroxide as hydrogen cannot be determined. Possible $\mathrm{Pb}-\mathrm{Mn}$ (hydr) oxides are cesàrolite, $\mathrm{Pb}\left(\mathrm{Mn}^{4+}\right)_{3} \mathrm{O}_{6}(\mathrm{OH})_{2}$ (Pechiazzi et al. 2008), quenselite, $\mathrm{PbMnO}_{2}(\mathrm{OH})$ (Rouse 1971) and various amorphous phases.

Copper, which is predominantly bound to fraction 3 in sample L12, is, however not bound to rather simple Fe-Mn (hydr)oxides like suggested by SCE, but is associated with a complex $\mathrm{Cu}-\mathrm{Fe}-\mathrm{Ni}-\mathrm{Sb}-\mathrm{As}-\mathrm{S}$ compound. Interestingly, As is also identified in the same compound in sample L12 
Table 4 Metal contents, dominant mineralogical bonding of metals in the investigated samples according to SCE and EMPA

\begin{tabular}{|c|c|c|c|c|c|}
\hline & As & $\mathrm{Cr}$ & $\mathrm{Cu}$ & $\mathrm{Ni}$ & $\mathrm{Pb}$ \\
\hline \multirow[t]{3}{*}{ L1 } & $0 \mathrm{mg} / \mathrm{kg}$ DS & $100 \mathrm{mg} / \mathrm{kg}$ DS & $47 \mathrm{mg} / \mathrm{kg}$ DS & 56 mg/kg DS & $285 \mathrm{mg} / \mathrm{kg}$ DS \\
\hline & $\begin{array}{l}\text { SCE: Fraction 1: } \\
\text { exchangeable }\end{array}$ & $\begin{array}{l}\text { SCE: } \text { Residue }=\text { bound to } \\
\text { crystalline phases }\end{array}$ & $\begin{array}{l}\text { SCE: } \text { Residue = bound to } \\
\text { crystalline phases }\end{array}$ & $\begin{array}{l}\text { SCE: } \text { Residue = bound to } \\
\text { crystalline phases }\end{array}$ & $\begin{array}{l}\text { SCE: Fraction 3: Fe and } \\
\text { Mn (hyd)oxides }\end{array}$ \\
\hline & EMPA: n.a. & $\begin{array}{l}\text { EMPA: Chromian spinel } \\
(\mathrm{Fe}, \mathrm{Mg})(\mathrm{Al}, \mathrm{Cr})_{2} \mathrm{O}_{4}\end{array}$ & EMPA: n.d. & EMPA: n.d. & EMPA: n.d. \\
\hline \multirow[t]{3}{*}{ L2 } & 87 mg/kg DS & $94 \mathrm{mg} / \mathrm{kg}$ DS & $68 \mathrm{mg} / \mathrm{kg} \mathrm{DS}$ & $58 \mathrm{mg} / \mathrm{kg} \mathrm{DS}$ & $455 \mathrm{mg} / \mathrm{kg} \mathrm{DS}$ \\
\hline & $\begin{array}{l}\text { SCE: } \text { Residue = bound to } \\
\text { crystalline phases }\end{array}$ & $\begin{array}{l}\text { SCE: } \text { Residue = bound to } \\
\text { crystalline phases }\end{array}$ & $\begin{array}{l}\text { SCE: } \text { Residue = bound to } \\
\text { crystalline phases }\end{array}$ & $\begin{array}{l}\text { SCE: Residue = bound to } \\
\text { crystalline phases }\end{array}$ & $\begin{array}{l}\text { SCE: Fraction 3: Fe and } \\
\text { Mn (hyd)oxides }\end{array}$ \\
\hline & EMPA: n.a. & EMPA: n.d. & EMPA: n.d. & EMPA: n.d. & $\begin{array}{l}\text { EMPA: Pb-Mn (hydr) } \\
\text { oxide }\end{array}$ \\
\hline \multirow[t]{3}{*}{ L5 } & $17 \mathrm{mg} / \mathrm{kg}$ DS & $140 \mathrm{mg} / \mathrm{kg} \mathrm{DS}$ & $40 \mathrm{mg} / \mathrm{kg} \mathrm{DS}$ & $58 \mathrm{mg} / \mathrm{kg} \mathrm{DS}$ & $860 \mathrm{mg} / \mathrm{kg} \mathrm{DS}$ \\
\hline & $\begin{array}{l}\text { SCE: } \text { Residue = bound to } \\
\text { crystalline phases }\end{array}$ & $\begin{array}{l}\text { SCE: } \text { Residue = bound to } \\
\text { crystalline phases }\end{array}$ & $\begin{array}{l}\text { SCE: } \text { Residue = bound to } \\
\text { crystalline phases }\end{array}$ & $\begin{array}{l}\text { SCE: } \text { Residue = bound to } \\
\text { crystalline phases }\end{array}$ & $\begin{array}{l}\text { SCE: Fraction 3: Fe and } \\
\text { Mn (hyd)oxides }\end{array}$ \\
\hline & EMPA: n.d. & EMPA: n.d. & EMPA: n.d. & EMPA: n.a. & $\begin{array}{l}\text { EMPA: Pb-Mn (hydr) } \\
\text { oxide }\end{array}$ \\
\hline \multirow[t]{3}{*}{ L7 } & $31 \mathrm{mg} / \mathrm{kg}$ DS & $125 \mathrm{mg} / \mathrm{kg} \mathrm{DS}$ & $47 \mathrm{mg} / \mathrm{kg} \mathrm{DS}$ & $63 \mathrm{mg} / \mathrm{kg}$ DS & $140 \mathrm{mg} / \mathrm{kg} \mathrm{DS}$ \\
\hline & $\begin{array}{l}\text { SCE: } \text { Residue = bound to } \\
\text { crystalline phases }\end{array}$ & $\begin{array}{l}\text { SCE: } \text { Residue = bound to } \\
\text { crystalline phases }\end{array}$ & $\begin{array}{l}\text { SCE: } \text { Residue = bound to } \\
\text { crystalline phases }\end{array}$ & $\begin{array}{l}\text { SCE: } \text { Residue = bound to } \\
\text { crystalline phases }\end{array}$ & $\begin{array}{l}\text { SCE: Fraction 3: Fe and } \\
\text { Mn (hyd)oxides }\end{array}$ \\
\hline & EMPA: n.a. & $\begin{array}{l}\text { EMPA: Chromian spinel } \\
\qquad(\mathrm{Fe}, \mathrm{Mg})(\mathrm{Al}, \mathrm{Cr})_{2} \mathrm{O}_{4}\end{array}$ & EMPA: n.d. & EMPA: n.d. & $\begin{array}{l}\text { EMPA: Pb-Mn (hydr) } \\
\text { oxide }\end{array}$ \\
\hline \multirow[t]{3}{*}{ L11 } & $23 \mathrm{mg} / \mathrm{kg}$ DS & $101 \mathrm{mg} / \mathrm{kg} \mathrm{DS}$ & $200 \mathrm{mg} / \mathrm{kg} \mathrm{DS}$ & $46 \mathrm{mg} / \mathrm{kg}$ DS & $18 \mathrm{mg} / \mathrm{kg} \mathrm{DS}$ \\
\hline & $\begin{array}{l}\text { SCE: } \text { Residue = bound to } \\
\text { crystalline phases }\end{array}$ & $\begin{array}{l}\text { SCE: } \text { Residue = bound to } \\
\text { crystalline phases }\end{array}$ & $\begin{array}{l}\text { SCE: Fraction 3: Fe and } \\
\text { Mn (hyd)oxides }\end{array}$ & $\begin{array}{l}\text { SCE: Residue = bound to } \\
\text { crystalline phases }\end{array}$ & $\begin{array}{l}\text { SCE: Fraction 3: Fe and } \\
\text { Mn (hyd)oxides }\end{array}$ \\
\hline & EMPA: n.a. & EMPA: n.d. & EMPA: n.d. & EMPA: n.d. & EMPA: n.d. \\
\hline \multirow[t]{3}{*}{ L12 } & $165 \mathrm{mg} / \mathrm{kg} \mathrm{DS}$ & $54 \mathrm{mg} / \mathrm{kg}$ DS & $2030 \mathrm{mg} / \mathrm{kg}$ & $36 \mathrm{mg} / \mathrm{kg}$ DS & $115 \mathrm{mg} / \mathrm{kg} \mathrm{DS}$ \\
\hline & $\begin{array}{l}\text { SCE: } \text { Residue = bound to } \\
\text { crystalline phases }\end{array}$ & $\begin{array}{l}\text { SCE: } \text { Residue = bound to } \\
\text { crystalline phases }\end{array}$ & $\begin{array}{l}\text { SCE: Fraction 3: Fe and } \\
\text { Mn (hyd)oxides }\end{array}$ & $\begin{array}{l}\text { SCE: Residue = bound to } \\
\text { crystalline phases }\end{array}$ & $\begin{array}{l}\text { SCE: } \text { Residue }=\text { bound to } \\
\text { crystalline phases }\end{array}$ \\
\hline & $\begin{array}{l}\text { EMPA: } \mathrm{Cu}-\mathrm{Fe}-\mathrm{Ni}-\mathrm{Sb}- \\
\text { As-S compound }\end{array}$ & EMPA: n.d. & $\begin{array}{l}\text { EMPA: } \mathrm{Cu}-\mathrm{Fe}-\mathrm{Ni}-\mathrm{Sb}- \\
\text { As-S compound }\end{array}$ & EMPA: n.a. & EMPA: n.d. \\
\hline \multirow[t]{3}{*}{ L22 } & $0 \mathrm{mg} / \mathrm{kg}$ DS & $455 \mathrm{mg} / \mathrm{kg} \mathrm{DS}$ & $26 \mathrm{mg} / \mathrm{kg}$ DS & $615 \mathrm{mg} / \mathrm{kg} \mathrm{DS}$ & $22 \mathrm{mg} / \mathrm{kg}$ DS \\
\hline & $\begin{array}{l}\text { SCE: no As detected } \\
\text { EMPA: n.a. }\end{array}$ & $\begin{array}{l}\text { SCE: } \text { Residue = bound to } \\
\text { crystalline phases }\end{array}$ & $\begin{array}{l}\text { SCE: } \text { Residue = bound to } \\
\text { crystalline phases }\end{array}$ & $\begin{array}{l}\text { SCE: } \text { Residue = bound to } \\
\text { crystalline phases }\end{array}$ & $\begin{array}{l}\text { SCE: } \text { Residue = bound to } \\
\text { crystalline phases }\end{array}$ \\
\hline & & $\begin{array}{l}\text { EMPA: } \mathrm{Cr} \text { spinel }(\mathrm{Fe}, \mathrm{Mg}) \\
(\mathrm{Al}, \mathrm{Cr})_{2} \mathrm{O}_{4}\end{array}$ & EMPA: n.d. & $\begin{array}{l}\text { EMPA: Olivine } \\
\quad(\mathrm{Fe}, \mathrm{Mg}, \mathrm{Ni})_{2} \mathrm{SiO}_{4}\end{array}$ & EMPA: n.d. \\
\hline
\end{tabular}

n.d. not detected, n.a. not analysed

in EMPA, although it behaves differently in SCE as it was predominantly present in the residual fraction.

Chromium, which is suggested to be present in crystalline phases by SCE, as it is enriched in the residual fraction, is confirmed to be incorporated in spinels $\left[(\mathrm{Fe}, \mathrm{Mg})(\mathrm{Al}, \mathrm{Cr})_{2} \mathrm{O}_{4}\right]$ by EMPA in samples L1, L7 and L22. Incorporation of $\mathrm{Cr}$ in spinels (L1, L7, L22) is in agreement with studies showing the presence of $\mathrm{Cr}$ in spinels in serpentine soils and an incongruent dissolution progressively enriching the spinel towards the chromite endmember (Oze et al. 2004).

For Ni, which is also suggested to be incorporated into crystalline phases, EMPA results reveal one exact mineralogical bonding in sample L22, where it is present as olivine, which has the stoichiometric formula $\left[(\mathrm{Fe}, \mathrm{Mg})_{2} \mathrm{SiO}_{4}\right]$, but can incorporate some $\mathrm{Ni}$ instead of $\mathrm{Fe}$ or $\mathrm{Mg}$.

With respect to the origin of the metals, neither SCE nor EMPA results yield unambiguous information. Firstly, anthropogenic metal contents can be mobile (e.g. $\mathrm{Sb}$ in municipal solid waste incineration bottom ashes (Cornelis et al. 2006)] or immobile [e.g. Cr in steel slags (Aldrian et al. 2015)], but also geogenic metal contents can be mobile [e.g. Cd in soils (Liu et al. 2013)] or immobile [e.g. Cr in ultramafic rocks (Altenburger et al. 2015)]. Secondly, many natural minerals possess synthetic analogues with the same composition and crystal structure, e.g. wuestite $(\mathrm{FeO})$ or members of the spinel and melilite group (Neuhold et al. 2019). In the investigated samples L1, L7 and L22 Ni-bearing olivine and $\mathrm{Cr}$-bearing spinels are likely to be anthropogenic, as both minerals are common in the Kraubath complex in the investigated region (Kollegger et al. 2007). The complex compound found in sample L12 could not be identified as a naturally occurring mineral, but this might be due to fine intergrowths of different mineral phases and does not indicate an anthropogenic source. In case of metals which are sorbed onto $\mathrm{Pb}-\mathrm{Mn}$ hydroxides, their primary source is completely unclear and it cannot even be said if 
they entered the soil from the surface or were mobilized from the substrate underneath the soil.

\section{Conclusion}

The aim of the present study, the assessment of the mobility of metals in Styrian soils and the understanding of this mobility by the mineralogy, by a method combination of SCE and EMPA was reached.

Although the exact mechanisms of release are not completely clear, SCE predicted quite well the mineralogical bonding of $\mathrm{Cr}$, Ni and As, to the groups given by Tessier et al. (1979). The mobility of metals from the investigated Styrian soil samples was not known before and represents a major finding of this study. Additionally, these novel findings could be explained by identifying distinct mineral phases which host the respective metals and limit their availability. In particular, the finding of the complex As phase in sample L12 adds a new piece of information to the As mineralogy in Styrian soils. Minor deviations between SCE and EMPA results, e.g. in case of $\mathrm{Cu}$ bonding, do not contradict the use of SCE, as especially in this case the diverse speciation of $\mathrm{Cu}$ is indicated.

Regarding mineralogical investigations, the suggested sorption mechanisms onto Fe or Mn (hydr)oxides, the added value of EMPA results is limited, as sorption and incorporation cannot be distinguished. In situ spectroscopic techniques like X-ray adsorption spectroscopy (Nevidomskaya et al. 2016) might be a suitable tool, but are highly complex and not suitable for quality control in compost soil production. Another challenge is the quite high detection limit of EMPA which prevented the identification of the mineralogical bonding of $\mathrm{Hg}$ and $\mathrm{Cd}$. Laser ablation inductively coupled plasma mass spectrometry (LA-ICP-MS) might be used for this purpose, but spatial resolution is worse than for EMPA. Recently, the authors have tested secondary ion mass spectrometry on the nanoscale (nanoSIMS) and obtained interesting results regarding the incorporation of metals in slags, but differentiation between sorption and incorporation is still not possible as long as samples have to be dried prior to analyses.

With respect to the objective to give further arguments to the authorities to replace pseudo-total contents as limit values for the recycling of excavated soils, the current study indicates that a combination of SCE and EMPA yields additional information to the mobility of metals in (excavated) soils which is relevant for their possible recycling despite exceeded limit values for pseudo-total content.

However, for standardization in waste management, both SCE and EMPA might be too complex methods and more simple methods need to be investigated. In this context it has to be mentioned that in certain legislations, a difference is made between geogenic and anthropogenic metal contaminations. Since SCE will not give any information about a geogenic or anthropogenic origin of a metal there is need to further examine methods for such a distinction. Wellacher et al. (2018) proposed to use the comparison of metal contents in different soil depths as well as in different size fractions. However, more research is needed for this distinction.

Acknowledgements Open access funding provided by Montanuniversität Leoben. The authors thank the Austrian Research Promotion Agency which funded the project ReSoil under Grant Agreement 848451, Alexia Aldrian and her team for chemical analyses and Federica Zaccarini for mineralogical analyses, and finally Thomas Sammer for support in the revision of the paper. We also thank Susana Casaseca, Hannah Kunodi, Markus Brechlmacher, Franz Poschacher, Anto Jelecevic and Peter Liebhard for the excellent collaboration within the project.

\section{Compliance with ethical standards}

Conflict of interest The authors declare that they have no conflict of interest.

Open Access This article is licensed under a Creative Commons Attribution 4.0 International License, which permits use, sharing, adaptation, distribution and reproduction in any medium or format, as long as you give appropriate credit to the original author(s) and the source, provide a link to the Creative Commons licence, and indicate if changes were made. The images or other third party material in this article are included in the article's Creative Commons licence, unless indicated otherwise in a credit line to the material. If material is not included in the article's Creative Commons licence and your intended use is not permitted by statutory regulation or exceeds the permitted use, you will need to obtain permission directly from the copyright holder. To view a copy of this licence, visit http://creativecommons.org/licenses/by/4.0/.

\section{References}

Aldrian A, Raith J, Höllen D, Pomberger R (2015) Influence of chromium containing spinels in an electric arc furnace slag on the leaching behaviour. J Solid Waste Technol Manag 41(4):357-365

Altenburger I, Schweiger G, Aldrian A, Höllen D (2015) Mineralogy and leachability of austrian rocks used in road construction. Mitteilungen der Österreichischen Mineralogischen Gesellschaft $61: 16$

Arcon I, van Elteren J, Glass H, Kodre A, Slejkovec Z (2005) EXAFS and XANES study of arsenic in contaminated soil. X-ray Spectrom 34:435-438

Arenas-Lago D, Lago-Vila M, Rodríguez-Seijo A, Andrade ML, Vega FA (2014) Risk of metal mobility in soils from a $\mathrm{Pb} / \mathrm{Zn}$ depleted mine (Lugo, Spain). Environ Earth Sci 72:2541-2556

Austrian Standards International (2002a) ÖNORM EN 13656Charakterisierung von Abfällen-Aufschluss mittels Mikrowellengerät mit einem Gemisch aus Fluorwasserstoffsäure ( $\mathrm{HF})$, Salpetersäure $\left(\mathrm{HNO}_{3}\right)$ und Salzsäure $(\mathrm{HCl})$ für die anschließende Bestimmung der Elemente im Abfall, Wien

Austrian Standards International (2002b) ÖNORM EN 13657Charakterisierung von Abfällen-Aufschluss zur anschließenden 
Bestimmung des in Königswasser löslichen Anteils an Elementen in Abfällen, Wien

Austrian Standards International (2004) ÖNORM L 1056Probenahme von Dauergrünland (inklusive Parkanlagen sowie Zier- und Sportrasen), Wien

Austrian Standards International (2007) ÖNORM EN 14346-Charakterisierung von Abfällen-Berechnung der Trockenmasse durch Bestimmung des Trockenrückstandes oder des Wassergehaltes, Wien

Austrian Standards International (2011) ÖNORM S 2127-Grundlegende Charakterisierung von Abfallhaufen oder von festen Abfällen aus Behältnissen und Transportfahrzeugen, Wien

Austrian Standards International (2012a) ÖNORM EN 15933Schlamm, behandelter Bioabfall und Boden-Bestimmung des $\mathrm{pH}-$ Wertes, Wien

Austrian Standards International (2012b) ÖNORM L 1053-Bodenuntersuchungen-Allgemeine Grundlagen, Wien

Austrian Standards International (2012c) ÖNORM EN 16169Schlamm, behandelter Bioabfall und Boden-Bestimmung des Kjeldahl-Stickstoffs, Wien

Austrian Standards International (2013) ÖNORM L 1080—Chemische Bodenuntersuchungen-Bestimmung des organischen Kohlenstoffs durch trockene Verbrennung mit und ohne Berücksichtigung von Carbonate

Austrian Standards International (2015) ÖNORM L 1099-Chemische Bodenuntersuchungen-Bestimmung der spezifischen elektrischen Leitfähigkeit, Wien

Austrian Standards International (2016) ÖNORM L 1084—Chemische Bodenuntersuchungen-Bestimmung von Carbonat unter Berücksichtigung von Luftdruck und Temperatur, Wien.

Austrian Standards International (2017) ÖNORM EN ISO 17294-2Wasserbeschaffenheit-Anwendung der induktiv gekoppelten Plasma-Massenspektrometrie (ICP-MS) - Teil 2: Bestimmung von ausgewählten Elementen einschließlich Uran-Isotope, Wien

Austrian Standards International (2019a) ÖNORM L 1087-Chemische Bodenuntersuchungen-Bestimmung von "pflanzenverfügbarem" Phosphor und Kalium nach der Calcium-Acetat-Lactat (CAL)-Methode, Wien

Austrian Standards International (2019b) ÖNORM L 1061-2_-Physikalische Bodenuntersuchungen-Bestimmung der Korngrößenverteilung des Mineralbodens in land- und forstwirtschaftlich genutzten Böden-Teil 2: Feinboden

Bacon J, Davidson C (2008) Is there a future for sequential chemical extraction. Analyst 133:25-46

Basu A, Schreiber ME (2013) Arsenic release from arsenopyrite weathering: Insights from sequential extraction and microscopic studies. J Hazard Mater 262:896-904

Beesley L, Marmiroli M (2011) The immobilisation and retention of soluble arsenic, cadmium and zinc in biochar. Environ Pollut 159:474-480

Borgigno L, Orona C, Avena M, Maine MA, Rodríguez A, De Pauli CP (2006) Phosphate concentration and association as revealed by sequential extraction and microprobe analysis: The case of sediments from two Argentinean reservoirs. Water Resour Res 42:W01414

Byrne P, Taylor KG, Hudson-Edwards KA, Barrett JES (2017) Speciation and potential long-term behaviour of chromium in urban sediment particulates. J Soils Sediments 17:2666-2676

Cappuyns V (2014) Background values of cobalt in Flemish and European soils. Geol Belgica 17(2):107-114

Cerqueira B, Vega FA, Serra C, Silva LFO, Andrade ML (2011) Time of flight secondary ion mass spectrometry and high-resolution transmission electron microscopy/energy dispersive spectroscopy: a preliminary study of the distribution of $\mathrm{Cu}^{2+}$ and $\mathrm{Cu}^{2+} / \mathrm{Pb}^{2+}$ on a Bt horizon surfaces. J Hazard Mater 195:422-431
Cerqueira B, Vega FA, Silva LFO, Andrade ML (2012) Effects of vegetation on chemical and mineralogical characteristics of soils developed on a decantation bank from a copper mine. Sci Total Environ 421-422:220-229

Commission of the European Communities (2000) Communication from the Commission on the precautionary principle. https:// publications.europa.eu/en/publication-detail/-/publication/21676 661-a79f-4153-b984-aeb28f07c80a/language-en. Accessed 18 July 2019

Cornelis G, van Gerven T, Vandecasteele C (2006) Antimony leaching from uncarbonated and carbonated MSWI bottom ash. J Hazard Mater 137(3):1284-1292

Degryse F, Smolders E, Parker D (2009) Partitioning of metals (Cd Co, $\mathrm{Cu}, \mathrm{Ni}, \mathrm{Pb}, \mathrm{Zn})$ in soils: concepts, methodologies, prediction and applications: a review. Eur J Soil Sci 60:590-612

Dijkstra J, Meeussen J, Comans R (2004) Leaching of heavy metals from contaminated soils: an experimental and modeling study. Environ Sci Technol 38:4390-4395

Downs R, Pinch W, Thompson R, Evans S, Megaw L (2016) Yangite, $\mathrm{PbMnSi}_{3} \mathrm{O}_{8} \cdot \mathrm{H}_{2} \mathrm{O}$, a new mineral species with double wollastonite silicate chains, from the Kombat mine, Namibia. Am Miner 101:2539-2543

Drobnik T, Greiner L, Keller A, Grêt-Regamy A (2018) Soil quality indicators-from soil functions to ecosystem services. Ecol Indic 94:151-169

Federal Ministry for Sustainability and Tourism (2017) Federal Waste Management Plan.

Federal Ministry for Sustainability and Tourism (2019) Die Bestandsaufnahme der Abfallwirtschaft in Österreich (engl.: The current state of waste management in Austria)

Filgueiras AV, Lavilla I, Bendicho C (2002) Chemical sequential extraction for metal partitioning in environmental solid samples. J Environ Monit 4:823-857

Fleming M, Tai Y, Zhuang P, McBride MB (2013) Extractability and bioavailability of $\mathrm{Pb}$ and $\mathrm{As}$ in historically contaminated orchard soil: effects of compost amendments. Environ Pollut 177:90-97

Höllen D, Neuhold S, Mudersbach D, Schüler S, Sommerauer H, Griessacher T, Dijkstra J, van Zomeren A, Presoly P, Schenk J, Pomberger R (2017) Möglichkeiten und Grenzen von Modellen zur Vorhersage der Auslaugbarkeit von Stahlwerksschlacken. Mineralische Nebenprodukte und Abfälle 4:205-222

Hrsak J, Furgass M, Vadjic V (2000) Soil contamination by Pb, Zn and Cd from a lead smeltery. Environ Monit Assess 60(3):359-366

Hseu ZY, Su YC, Zehetner F, Hsi HC (2017) Leaching potential of geogenic nickel in serpentine soils from Taiwanand Austria. J Environ Manag 186:151-157

Jelecevic A, Horn D, Eigner H, Sager M, Liebhard P, Moder K, Vollprecht D (2019) Kinetics of lead release from soils at historic mining and smelting sites, determined by a modified electroultrafiltration. Plant Soil Environ 65:298-306

Jensen P, Ottosen L, Pedersen A (2006) Speciation of Pb in industrially polluted soils. Water Air Soil Pollut 170:359-382

Kabata-Pendias A, Pendias H (2001) Trace elements in soils and plants, 3rd edn. CRC Press LLC, Boca Raton

Kierczak J, Neel C, Aleksander-Kwaterczak U, Helios-Rybicka E, Bril H, Puziewicz J (2008) Solid speciation and mobility of potentially toxic elements from natural and contaminated soils: a combined approach. Chemosphere 73(5):776-784

Kollegger P, Mogessie A, Mali H (2007) Geochemie und Vererzung im Kraubath-Massiv, südöstlich von Kraubath an der Mur, Steiermark, Österreich. Joannea Mineralogie 4:53-97

Krainer W (1999) Bodenschutzbericht 1999_-Potentielle Kontaminationsflächen in der Steiermark. Landwirtschaftliches Versuchszentrum Steiermark, Graz 
Lang F, Kaupenjohann M (2003) Effect of dissolved organic matter on the precipitation and mobility of the lead compound chloropyromorphite in solution. Eur J Soil Sci 54:139-147

Li X, Coles B, Ramsey M, Thornton I (1995) Sequential extraction of soils for multielement analysis by ICP-AES. Chem Geol 124:109-123

Liu Y, Xiao T, Ning Z, Li H, Tang J, Zhou G (2013) High cadmium concentration in soil in the three Gorges region: geogenic source and potential bioavailability. Appl Geochem 37:149-156

Lombi E, Sletten RS, Wenzel WW (2000) Sequentially extracted arsenic from different size fractions of contaminated soils. Water Air Soil Pollut 124(3-4):319-332

Majzlan J, Kiefer S, Herrmann J, Stevko M, Sejkora J, Chovan M, Lánczos T, Lazarov M, Gerdes A, Langenhorst F, Borčinová Radková A, Jamieson H, Milovsky R (2018) Synergies in elemental mobility during weathering of tetrahedrite $[(\mathrm{Cu}, \mathrm{Fe}$, $\mathrm{Zn}$ )12(Sb, As)4S13]: field observations, electron microscopy, isotopes of $\mathrm{Cu}, \mathrm{C}, \mathrm{O}$, radiometric dating, and water geochemistry. Chem Geol 488:1-20

Moral R, Gilkes RJ, Jordán MM (2005) Distribution of heavy metals in calcareous and non-calcareous soils in Spain. Water Air Soil Pollut 162(1-4):127-142

Neuhold S, van Zomeren A, Dijkstra J, van der Sloot H, Drissen P, Algermissen D, Mudersbach D, Schüler S, Griessacher T, Raith J, Pomberger R, Vollprecht D (2019) Investigation of possible leaching control mechanisms for chromium and vanadium in electric arc furnace (EAF) slags using combined experimental and modeling approaches. Minerals 9(9):525

Nevidomskaya D, Minkina T, Soldatov A, Shuvaeva V, Zubavichus Y, Podkovyrina Y (2016) Comprehensive study of Pb (II) speciation in soil by X-ray absorption spectroscopy (XANES and EXAFS) and sequential fractionation. J Soil Sediment 16(4):1183-1192

Nielsen MT, Scott-Fordsmand JJ, Murphy MW, Kristiansen SM (2015) Speciation and solubility of copper along a soil contamination gradient. J Soil Sediment 15:1558-1570

Oze C, Fendorf S, Bird D, Coleman R (2004) Chromium geochemistry in serpentinized ultramafic rocks and serpentine soils from the Franciscan complex of California. Am J Sci 304:67-101

Pechiazzi N, Hatert F, Merlino SB (2008) Cesàrolite, a possible member of the birnessite group of minerals. International workshop on layered materials, Vercelli, Italy

Quian J, Shan XQ, Wang ZJ, Tu Q (1996) Distribution and plant availability of heavy metals in different particle-size fractions of soil. Sci Total Environ 187:131-141
Rao C, Sahuquillo A, Lopez Sanchez J (2008) A review of the different methods applied in environmental geochemistry for single and sequential extraction of trace elements in soils and related materials. Water Air Soil Pollut 189:291-333

Rinklebe J, Shaheen S (2014) Assessing the mobilization of cadmium, lead, and nickel using a seven-step sequential extraction technique in contaminated floodplain soil profiles along the central Elbe River, Germany. Water Air Soil Pollut 225(8):2039-2058

Roberts D, Scheinost A, Sparks D (2002) Zinc speciation in a smeltercontaminated soil profile using bulk and microspectroscopic techniques. Environ Sci Technol 36(8):1742-1750

Rodgers K, McLellan I, Cuthbert S, Hursthouse A (2019) Enhanced characterisation for the management of industrial steel processing by products: potential of sequential chemical extraction. Environ Monit Assess 191(3):1-19

Rouse R (1971) The crystal structure of quenselite. Z Kristallogr Cryst Mater 134(5-6):321-332

Santos R, van Audenaerde A, Chiang Y, Iacobescu R, Knops P, van Gerven T (2015) Nickel extraction from olivine: effect of carbonation pre-treatment. Metals 5(3):1620-1644

Sedlazeck KP, Höllen D, Müller P, Mischitz R, Gieré R (2017) Mineralogical and geochemical characterization of a chromium contamination in an aquifer-a combined analytical and modeling approach. Appl Geochem 87:44-56

Shaheen S, Rinklebe J (2014) Geochemical fractions of chromium, copper, and zinc and their verticaldistribution infloodplain soil profiles along the Central Elbe River, Germany. Geoderma 228-229:142-159

Shaheen S, Rinklebe J, Tsadilas C (2015) Fractionation and Mobilization of toxic elements in floodplain soils from Egypt, Germany, and Greece: a comparsion study. Eurasian Soil Sci+ 48(12):1317-1328

Tessier A, Campbell P, Bisson M (1979) Sequential extraction procedure for the speciation of particulate trace metals. Anal Chem 51(7):844-851

The United Nations Conference on Environment and Development (1992) The Rio Declaration on Environment and Development

Wellacher M, Pomberger R, Vollprecht D, Poschacher F, Liebhard P, Jelecevic A (2018) Verwertung von Aushubmaterialien. Recy\&DepoTech 14:745-752

Young S (2013) Chemistry of heavy metals and metalloids in soils. In: Alloway B (ed) Heavy metals in soils, 3rd edn. Springer, Dordrecht, pp 51-95 